\title{
PENGARUH AKSES PERMODALAN, PENGELOLAAN BISNIS \\ TERHADAP PEMBERDAYAAN USAHA PEDAGANG KAKI LIMA \\ DENGAN PERAN PEMERINTAH DAERAH SEBAGAI VARIABEL INTERVENING (KASUS PKL DI KABUPATEN KEBUMEN)
}

\author{
Sigit Wibawanto, SE., MM \\ Hendrawan Prasetyo, S.Sos.
}

\begin{abstract}
ABSTRAKSI
Dewasa ini program pemberdayaan ekonomi kerakyatan menjadi isu sentral yang seringkali didengungkan dan menuntut perhatian lebih dari pemerintah. Isu yang berkembang menjadi wacana menarik perhatian ini adalah pemberdayaan usaha kecil dan menengah. Kukuhnya industri kecil yang cenderung lebih stabil dibandingkan industri besar pada saat krisis multidimensional menjadikan munculnya upaya bahwa perhatian yang tepat saat ini adalah lebih terfokus pada ekonomi kerakyatan melalui pemberdayaan masyarakat. Realita saat ini adalah banyak kalangan masyarakat yang sudah mulai berani untuk membuka usaha baru, dan cenderung dengan modal awal kecil dengan perhitungan yang kurang maksimal, hal ini menunjukkan bahwa kecenderungan bisnis masih berdasarkan hitungan ikut-ikutan. Yang terjadi saat ini adalah banyak bermunculan usaha yang jarang sekali di konsep secara bisnis dan asal-asalan. Namun demikian ada pula yang berkembang karena sudah dipersiapkan secara matang dan siap untuk dikembangkan. Bisnis yang paling banyak dikembangkan oleh masyarakat saat ini adalah di emperan toko, tepi jalan, yang biasa disebut dengan Pedagang Kaki Lima (PKL).

Pedagang Kaki Lima (PKL) yang merupakan usaha mikro dari segi informal memang sangat perlu dikembangkan tentu saja disesuaikan dengan pemberdayaan ekonomi kerakyatan. Istilah Pedagang Kaki Lima (PKL) cenderung terkesan negatif, kaki lima pandangannya lebih negatif baik dari gangguan terhadap kelancaran lalu lintas, kumuh dan tidak bersih. Akan tetapi dengan konsep yang berubah, justru dari kaki limalah sumber perekonomian masyarakat bisa berkembang.
\end{abstract}

Kata kunci : ekonomi kerakyatan, usaha kecil menengah, pembardayaan masyarakat, Pedagang Kaki Lima (PKL) 


\section{PENDAHULUAN \\ Latar Belakang}

Maraknya program yang didengungkan yang menuntut perhatian pemerintah saat ini adalah pemberdayaan ekonomi kerakyatan. Isu yang berkembang menjadi wacana menarik perhatian ini adalah pemberdayaan usaha kecil dan menengah. Kukuhnya industri kecil yang cenderung lebih stabil dibandingkan industri besar pada saat krisis multi dimensional menjadikan ada upaya bahwa perhatian yang tepat saat ini adalah ekonomi kerakyatan. Perhatian inilah yang memunculkan banyak beberapa tokoh usahawan, motivator, dan trainer di bidang usahawan menjual program dan materi untuk diseminarkan, pelatihan dan sebagainya. Para tokoh ini menjadi sangat laku dan menjadi suatu bisnis entertaint baru di kancah dunia bisnis. Peluang yang begitu besar dengan memberikan masukan, dorongan bagi masyarakat mengenai pentingnya berwirausaha secara tidak kentara ada kegiatan sosial yang ditawarkan untuk membantu pemerintah. Kegiatan ini menjadi penting bagi pemerintah karena telah berperan serta dalam merubah pola pikir masyarakat yang cenderung bermental menjadi pekerja. Mental yang terbentuk tersebut akan menjadi sangat membebani pemerintah dalam penyediaan lapangan kerja, yang sangat terbatas.

Pengembangan mental yang telah dilakukan tokoh-tokoh ini adalah membangun mental entrepreneuship yang kecenderungannya adalah membuka usaha mandiri, baik secara pribadi, kelompok, maupun franchise. Artinya bahwa mental yang dibangun adalah mental usaha bukan pekerja, dan membangun usaha didasarkan atas kemauan, niat dan bukan atas bakat dan keturunan. Mental usaha yang ditawarkan adalah siapapun yang mau membuka dalam aksi yang tepat. Namun demikian banyak sekali usaha yang sudah dijalankan para entrepreneur bersifat opportunist entreprenur yaitu yang tertarik pada memaksimalkan hasil jangka pendek, sehingga mental yang telah terbentuk menjadi sia-sia. Sikap mental seperti ini misalnya; kurangnya kejujuran dalam usaha, mudah putus asa, dan kurangnya keberanian dalam mengambil resiko-resiko bisnis, dan sebagainya. Sehingga pengembangan dalam usaha ini menjadi terhambat. Membangan mental memanglah tidak mudah, namun prasyarat sebagai entrepreneur adalah selalu berpikir positif, memiliki daya tahan (survive), dan mampu memecahkan masalah-masalah (problem solving) yang berkaitan dengan bisnis.

Bagi siapapun yang mau berusaha dan mau berwirausaha semuanya adalah pilihan. Jenis entrepreneur yang paling umum adalah nascent entrepreneur, atau yang menjalankan bisnis tunggal (singular entrepreneur). Singular entrepreneur pada awal pengembangan usaha dalam tahap pembelajaran dikenal sebagai novice entrepreneur. Saat ini banyak sekali kalangan masyarakat sudah mulai berani untuk membuka usaha baru, dan kecenderungannya bermodal awal yang keci dengan perhitungan yang kurang maksimal, dimana kecenderungannya bisnis masih berdasarkan hitungan ikutikutan. Yang terjadi saat ini adalah banyak bermunculan usaha yang jarang 
sekali di konsep secara bisnis dan asal-asalan. Namun demikian ada pula yang berkembang karena sudah dipersiapkan secara matang dan siap untuk dikembangkan. Bisnis yang paling banyak dikembangkan oleh masyarakat saat ini adalah di emperan toko, tepi jalan, yang biasanya disebut dengan sebutan pedagang kaki lima.

Pedagang kaki lima yang merupakan usaha mikro dari segi informal memang sangat perlu dikembangkan disesuaikan dengan pemberdayaan ekonomi kerakyatan. Istilah pedagang kaki lima cenderungannya memang negatif, artinya bahwa kaki lima pandangannya lebih negatif baik dari gangguan terhadap kelancaran lalu lintas, kumuh dan tidak bersih. Akan tetapi dengan konsep yang berubah, justru dari kaki limalah sumber perekonomian masyarakat bisa berkembang. Pada setiap daerah di seluruh Indonesia keberadaan PKL (pedagang kaki lima) masih menjadi momok yang memprihatinkan sebagai ujung tombak perekonomian. Ini berkaitan dengan tanggapan negatif dari masyarakat tertentu yang terusik dengan keberadaan PKL, dan kebijakan masing-masing pemerintah daerah terhadap ketertiban dan keindahan daearah perkotaan.

Keberadaan PKL di Kabupaten Kebumen saat ini masih dinilai belum pada titik yang memprihatinkan dan masih relatif mudah untuk dikendalikan. PKL di kabupaten Kebumen tumbuh dan bergerak secara sporadis seperti jamur di musim penghujan. Apalagi dipicu oleh situasi dan kondisi ekonomi yang belum menguntungkan, dimana adanya keterbatasan pekerjaan disektor formal dan sulitnya pengembangan sumber daya alam. Oleh karena itu sangatlah wajar apabila banyak masyarakat mulai berpikir bagaimana mendapatkan dan meningkatkan penghasilan yang layak dalam rangka meningkatkan kesejahteraan keluarga.

Berkaitan dengan menjamurnya PKL saat ini di kabupaten Kebumen adalah bahwa apa yang terjadi saat ini dan masa mendatang akan berimplikasi pada munculnya berbagai macam persoalan ke permukaan, mulai dari kemacetan lalulintas, kesemrawutan dan ketidakteraturan kota, terganggunya estetika kota hingga polusi, bahkan mungkin tindak kejahatan. Oleh karena itulah perlu sekali untuk ditelusuri seluk beluk dan keberadaan PKL berikut akibat dan dampaknya, yang nantinya dijadikan input untuk berproses sehingga menghasilkan output berupa kebijakan Pemerintah Kabupaten yang berpihak pada sektor informal (PKL).

Berkaitan dengan fenomena tersebut, maka peneliti akan membahas mengenai bagaimana langkah yang terbaik dalam memberdayakan ekonomi yang berpihak pada masyarakat terutama PKL agar mampu menjadi komoditas masyarakat dalam mengembangkan perekonomian keluarga. Ini dapat dilihat dari akses ke lembaga permodalahan baik dari kemudahan prosedur, kemudahan dari jumlah permintaan modal, serta ketepatan pemberian kredit. Selain itu dari segi pengelolaan bisnis rata-rata PKL belum memiliki keahlian dalam sisi manajemen, yang meliputi aspek perencanaan, pengembangan usaha, maupun sisi kontrol dalam pengendalian resiko bisnis. Ini dikarenakan kurangnya ilmu terhadap pengelolaan usaha. Disisi lain tentunya perhatian 
pemerintah daerah akan dibutuhkan untuk menciptakan suatu ketertiban kota yang diharapkan dapat menopang pembangunan daerah tanpa harus membuat masalah bagi masyarakat yang lain serta menjaga ketertiban dan keindahan kota Kebumen.

\section{Tujuan Penelitian}

Tujuan dalam penelitian ini adalah untuk mengetahui pemberdayaan Usaha Pedagang Kaki Lima (PKL) di kabupaten Kebumen.

\section{TELAAH PUSTAKA}

\section{Konsep Pemberdayaan}

Konsep pemberdayaan masyarakat telah dikembangkan dalam berbagai literatur. Ini dibuktikan dengan adanya pembahasan pada tingkat internasional pada KTT Pembangunan Sosial di Kopenhagen Tahun 1992. Namun demikian dalam praktik pembangunan tidak selalu berjalan baik, yang disebabkan adanya perbedaaan kesepahaman mengenai dilema-dilema pembangunan yang dihadapi saat ini, disamping itu banyak pula ditemukan berbagai hal yang bias dari adanya konsep pemberdayaan masyarakat sebagai paradigma pembangunan.

Konsep pemberdayaan masyarakat menjadi suatu konsep pembangunan ekonomi baru yang menyangkut banyak nilai-nilai sosial masyarakat, yang bersifat people-centered, participatory, empowering, and sustainable (Chambers, 1995 dalam Kartasasmita, 1996). Konsep ini menurut Friedmann (1992) disebut alternative development, yang menghendaki inclusive democracy, appropriate economic growth, gender equality and intergenerational equity .

Hal yang perlu diketahui dari konsep pemberdayaan ini adalah pada dasarnya pemberdayaan tidak mempertentangkan pertumbuhan dengan pemerataan. Menurut Donald Brown (1995), keduanya bukan saja sebagai incompatible or antithetical, yang melepaskan diri dari perangkap zerosum game dan trade off, akan tetapi bertitik tolak dari pandangan pemerataan pertumbuhan dan jaminan pertumbuhan berkelanjutan.

Konsep pemberdayaan ini dibangun dari kerangka sebagai berikut:

1. Proses pemusatan kekuasaan terbangun dari pemusatan kekuasaan faktor produksi;

2. Pemusatan kekuasaan faktor produksi akan melahirkan masyarakat pekerja dan masyarakat pengusaha pinggiran;

3. Kekuasaan akan membangun bangunan atas atau sistem pengetahuan, sistem politik, sistem hukum dan sistem ideologi yang manipulatif untuk memperkuat legitimasi; dan

4. Pelaksanaan sistem pengetahuan, sistem politik, sistem hukum dan ideologi secara sistematik akan menciptakan dua kelompok masyarakat, yaitu masyarakat berdaya dan masyarakat tunadaya (Prijono dan Pranarka, 1996). 
Pemberdayaan itu sendiri (empowerment) berawal dari kata daya (power), yang berarti kekuatan yang berasal dari dalam tetapi dapat diperkuat dengan unsur unsur penguatan yang diserap dari luar. Keterbelakangan dan kemiskinan yang muncul dalam proses pembangunan disebabkan oleh ketidakseimbangan dalam pemilikan atau akses pada sumber sumber power. Proses historis yang panjang menyebabkan terjadinya power dis powerment, yakni peniadaan power pada sebagian besar masyarakat, akibatnya masyarakat tidak memiliki akses yang memadai terhadap akses produktif yang umumnya dikuasai oleh mereka yang memiliki power. Pada gilirannya keterbelakangan secara ekonomi menyebabkan mereka makin jauh dari kekuasaan. Begitulah lingkaran setan itu berputar terus.

Secara konseptual, pemberdayaan masyarakat adalah upaya untuk meningkatkan harkat dan martabat lapisan masyarakat yang dalam kondisi sekarang tidak mampu untuk melepaskan diri dari perangkap kemiskinan dan keterbelakangan. Menurut Prijono dan Pranarka (1996), konsep pemberdayaan manusia adalah subyek dari dirinya sendiri. Proses pemberdayaan yang menekankan pada proses memberikan kemampuan kepada masyarakat agar menjadi berdaya, mendorong atau memotivasi individu agar mempunyai kemampuan atau keberdayaan untuk menentukan pilihan hidupnya. Lebih lanjut dikatakan bahwa pemberdayaan harus ditujukan pada kelompok atau lapisan masyarakat yang tertinggal. Menurut Sumodiningrat (1999), bahwa pemberdayaan masyarakat merupakan upaya untuk memandirikan masyarakat lewat perwujudan potensi kemampuan yang mereka miliki. Adapun pemberdayaan masyarakat senantiasa menyangkut dua kelompok yang saling terkait, yaitu masyarakat sebagai pihak yang diberdayakan dan pihak yang menaruh kepedulian sebagai pihak yang memberdayakan. Mubyarto (1998) menekankan bahwa terkait erat dengan pemberdayaan ekonomi rakyat. Dalam proses pemberdayaan masyarakat diarahkan pada pengembangan sumberdaya manusia (di pedesaan), penciptaan peluang berusaha yang sesuai dengan keinginan masyarakat. Masyarakat menentukan jenis usaha, kondisi wilayah yang pada gilirannya dapat menciptakan lembaga dan sistem pelayanan dari, oleh dan untuk masyarakat setempat. Upaya pemberdayaan masyarakat ini kemudian pada pemberdayaan ekonomi rakyat.

Keberdayaan dalam konteks masyarakat adalah kemampuan individu yang bersenyawa dalam masyarakat dan membangun keberdayaan masyarakat yang bersangkutan. Suatu masyarakat yang sebagian besar anggotanya sehat fisik dan mental, terdidik dan kuat, tentunya memiliki keberdayaan yang tinggi. Keberdayaan masyarakat merupakan unsur dasar yang memungkinkan suatu masyarakat bertahan, dan dalam pengertian yang dinamis mengembangkan diri dan mencapai kemajuan. Keberdayaan masyarakat itu sendiri menjadi sumber dari apa yang di dalam wawasan politik disebut sebagai ketahanan nasional. Artinya bahwa apabila masyarakat memiliki kemampuan ekonomi yang tinggi, maka hal tersebut merupakan bagian dari ketahanan ekonomi nasional. 


\section{Pedagang Kaki Lima}

Di dalam UU. Nomor 9 Tahun 1995 tentang Usaha Kecil dijelaskan bahwa yang dimaksud dengan usaha kecil adalah kegiatan ekonomi rakyat yang berskala kecil dan memenuhi kriteria kekayaan bersih atau hasil penjualan tahunan serta kepemilikan. Usaha kecil ini meliputi: usaha kecil formal, usaha kecil informal dan usaha kecil tradisional. Usaha kecil formal adalah usaha yang telah terdaftar, tercatat dan telah berbadan hukum, sementara usaha kecil informal adalah usaha yang belum terdaftar, belum tercatat dan belum berbadan hukum, antara lain petani penggarap, industri rumah tangga, pedagang asongan, pedagang keliling, pedagang kaki lima dan pemulung. Sedangkan usaha kecil tradisional adalah usaha yang menggunakan alat produksi sederhana yang telah digunakan secara turun temurun dan/atau berkaitan dengan seni dan budaya.

Dalam UU. Nomor 9 Tahun 1995 juga ditetapkan beberapa Kriteria Usaha Kecil, antara lain (1) memiliki kekayaan bersih paling banyak 200 juta rupiah, tidak termasuk tanah dan bangunan tempat usaha; atau (2) memiliki hasil penjualan tahunan paling banyak 1 (satu) milyar rupiah; (3) milik warga negara Indonesia; (4) berdiri sendiri, bukan merupakan anak perusahaan atau cabang perusahaan yang dimiliki, dikuasai atau berafiliasi, baik langsung maupun tidak langsung dengan usaha menengah atau usaha besar; (5) berbentuk usaha orang perseorangan, badan usaha yang tidak berbadan hukum, atau badan usaha yang berbadan hukum, termasuk koperasi. Dengan demikian dapat disimpulkan bahwa Usaha Kaki Lima adalah bagian dari Kelompok Usaha Kecil yang bergerak di sektor informal, yang oleh istilah dalam UU. No. 9 Tahun 1995 di atas dikenal dengan istilah Pedagang Kaki Lima .

Swasono (1987) mengatakan bahwa adanya sektor informal bukan sekedar karena kurangnya lapangan pekerjaan, apalagi menampung lapangan kerja yang terbuang dari sektor informal akan tetapi sektor informal adalah sebagai pilar bagi keseluruhan ekonomi sektor formal yang terbukti idak efisien. Hal ini dapat menunjukan bahwa sektor informal telah banyak mensubsidi sektor formal, disamping sektor informal merupakan sektor yang efisien karena mampu menyediakan kehidupan murah.

Dieter-Evers dikutip Rachbini dan Hamid (1994) menganalogikan sektor informal sebagai sebuah bentuk ekonomi bayangan dalam negara. Ekonomi bayangan digambarkan sebagai kegiatan ekonomi yang tidak mengikuti aturanaturan yang dikeluarkan oleh pemerintah. Kegiatan ekonomi bayangan merupakan bentuk kegiatan ekonomi yang bergerak dalam unit-unit kecil sehingga bisa dipandang efisien dalam memberikan pelayanan. Dilihat dari sisi sifat produksinya, kegiatan ini bersifat subsistem yang bernilai ekonomis dalam pemenuhan kebutuhan sehari-hari khususnya bagi masyarakat yang ada dilingkungan sektor informal.

Hutajulu (1985) memberikan batasan tentang sektor informal, adalah suatu bidang kegiatan ekonomi yang untuk memasukinya tidak selalu memerlukan pendidikan formal dan keterampilan yang tinggi, dan memerlukan surat-surat izin serta modal yang besar untuk memproduksi barang dan jasa. 
Selanjutnya Sethurahman (1985) memberi batasan sektor informal ini sebagai unit-unit usaha berskala kecil yang terlibat dalam proses produksi dan distribusi barang-barang, dimasuki oleh penduduk kota terutama bertujuan untuk mencari kesempatan kerja dan pendapatan dari pada memperoleh keuntungan. Sedangkan menurut Moser, 1978 dalam Chandrakirana dan Sadoko (1995) bahwa sektor informal merupakan kegiatan ekonomi yang selama ini lolos dari pencacahan, pengaturan dan perlindungan pemerintah, tetapi mempunyai makna ekonomi dengan karakteristik kompetitif, padat karya, memakai input dan teknologi lokal, serta beroperasi atas dasar pemilikan sendiri oleh masyarakat lokal, serta beroperasi atas dasar pemilikan sendiri oleh masyarakat.

Menurut Rachbini dan Hamid (1994), sektor informal berfungsi sebagai penyedia barang dan jasa terutama bagi masyarakat golongan ekonomi menengah ke bawah yang tinggal dikota-kota. Pelaku sektor ini pada umumnya berasal dari desa-desa dengan tingkat pendidikan dan keterampilan rendah serta sumber-sumber terbatas.

Secara umum, pedagang dapat diartikan sebagai penyalur barang dan jasa-jasa perkotaan (Rais dalam Umboh, 1990). Adapun menurut McGee yang dikutip Young (1977) mendefinisikan pedagang kaki lima adalah The people who offer goods or services for ale from public places, primarily streetes and pavement. Sedangkan Manning dan Tadjudin Noer Effendi (1985) menyebutkan bahwa pedagang kaki lima adalah salah satu pekerjaan yang paling nyata dan penting dikebanyakan kota di Afrika, Asia, Timur Tengah dan Amerika Latin.

Menurut Breman (1988), pedagang kaki lima merupakan usaha kecil yang dilakukan oleh masyarakat yang berpenghasilan rendah (gaji harian) dan mempunyai modal yang terbatas. Dalam bidang ekonomi, pedagang kecil ini termasuk dalam sektor informal, di mana merupakan pekerjaan yang tidak tetap dan tidak trampil serta golongan-golongan yang tidak terikat pada aturan hukum, hidup serba susah dan semi kriminil pada batas-batas tertentu.

Dari pengertian/batasan tentang pedagang kaki lima sebagaimana dikemukakan beberapa ahli di atas, dapat dipahami bahwa pedagang kaki lima merupakan bagian dari kelompok usaha kecil yang bergerak di sektor informal. Secara khusus, pedagang kaki lima dapat diartikan sebagai distribusi barang dan jasa yang belum memiliki ijin usaha dan biasanya berpindah-pindah.

Menurut Wirosardjono (1985) pengertian pedagang kaki lima adalah kegiatan sektor marginal (kecil-kecilan) yang mempunyai ciri sebagai berikut:

a) Pola kegiatan tidak teratur baik dalam hal waktu, permodalan maupun penerimaannya.

b) Tidak tersentuh oleh peraturan-peraturan atau ketentuan-ketentuan yang ditetapkan oleh pemerintah (sehingga kegiatannya sering dikategorikan liar ).

c) Modal, peralatan dan perlengkapan maupun omzetnya biasanya kecil dan diusahakan dasar hitung harian.

d) Pendapatan mereka rendah dan tidak menentu. 
e) Tidak mempunyai tempat yang tetap dan atau keterikatan dengan usaha-usaha yang lain.

f) Umumnya dilakukan oleh dan melayani golongan masyarakat yang berpenghasilan rendah.

g) Tidak membutuhkan keahlian dan keterampilan khusus sehingga secara luas dapat menyerap bermacam-macam tingkatan tenaga kerja.

h) Umumnya tiap-tiap satuan usaha yang mempekerjakan tenaga yang sedikit dan dari lingkungan keluarga, kenalan atau berasal dari daerah yang sama.

i) Tidak mengenal sistem perbankan, pembukuan, perkreditan dan sebagainya.

j) Sebagai saluran arus barang dan jasa, pedagang kaki lima merupakan mata rantai akhir sebelum mencapai konsumen dari satu mata rantai yang panjang dari sumber utamanya yaitu produsennya (Ramli, 1984).

Berdasarkan barang atau jasa yang diperdagangkan, menurut Karafi dalam Umboh (1990), pedagang kaki lima dapat dikelompokkan sebagai berikut : 1). Pedagang minuman; 2). Pedagang makanan; 3). Pedagang buahbuahan; 4). Pedagang sayur-sayuran; 5). Pedagang daging dan ikan; 6). Pedagang rokok dan obat-obatan; 7). Pedagang buku, majalah dan surat kabar; 8). Pedagang tekstil dan pakaian; 9). Pedagang kelontong; 10). Pedagang loak; 11). Pedagang onderdil kendaraan, bensin dan minyak tanah; 12). Pedagang ayam, kambing, burung dan 13). Pedagang beras serta; 14). Penjual jasa.

\section{Kerangka Pemikiran}

Penelitian ini dilakukan dengan merancang kegiatan untuk mengetahui pemberdayaan usaha PKL dikabupaten Kebumen..

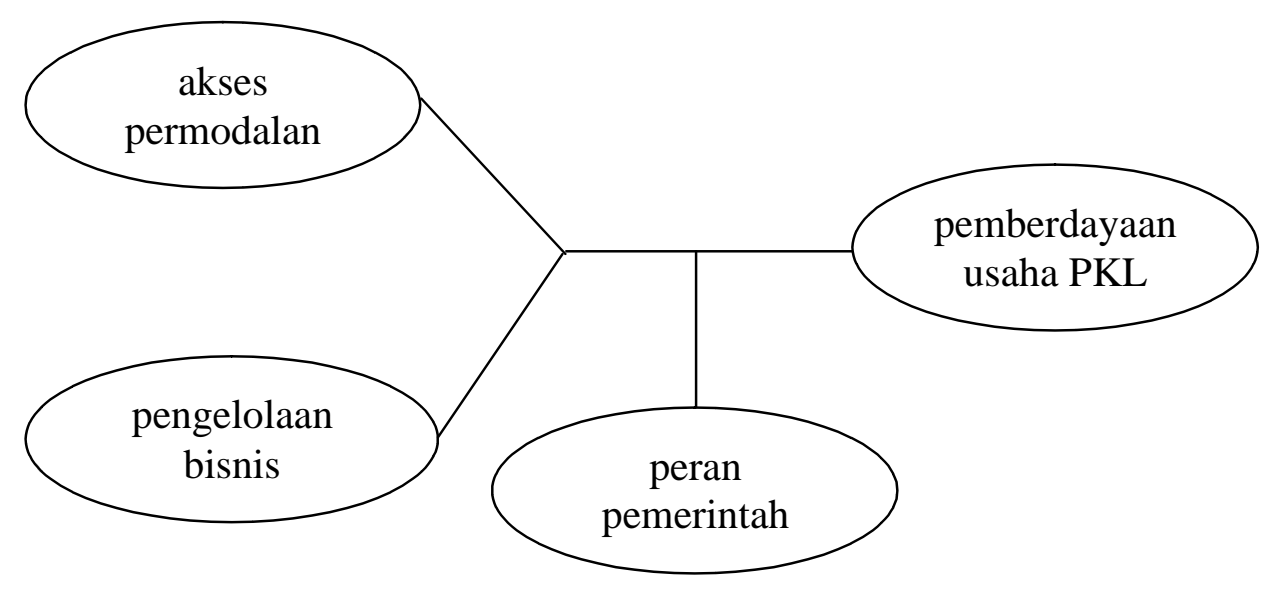

Gambar.1 Kerangka Pemikiran 


\section{Metodologi Penelitian}

Sampel yang digunakan dalam penelitian ini adalah 100 PKL yang ada di alun-alun kabupaten Kebumen. Data dalam penelitian ini adalah data primer dan data sekunder. Sumber data primer diperoleh dengan wawancara langsung maupun observasi dilapangan dengan para PKL. Sedang sumber data sekunder diperoleh dari pengumpulan data melalui sumber-sumber dari DIPENDA, DIPERINDAGKOP, serta dari BPS.

Analisa dalam penelitian ini dilakukan secara kualitatif dan kualitatif. Teknis analisis secara kualitatif dilakukan melalui proses penyederhanaan data dalam bentuk yang mudah dibaca dan diinterpretasikan (Masri Singarimbun dan Sofian Efendi (ed), 1989:263). Data dari lapangan maupun dari beberapa literatur yang berhasil dikumpulkan dipelajari serta dipilih yang sesuai dengan kebutuhan penelitian. Tahapan analisis ini dimulai dengan koding data yang kemudian ditampilkan (display) dalam bentuk tabel, grafik, diagram atau gambar tertentu, dan selanjutnya dianalisis dan disimpulkan. Sedang teknik analisis kuantitatif dilakukan dengan menggunakan alat bantu analisis yaitu Amos 4.0.

\section{PENUTUP}

Upaya pemberdayaan masyarakat telah mendapat perhatian besar dari berbagai pihak yang menyangkut pada aspek pemberdayaan ekonomi sosial, serta aspek pemberdayaan yang lain. Pemberdayaan masyarakat terkait dengan pemberian akses bagi masyarakat, lembaga, dan organisasi masyarakat dalam memperoleh dan memanfaatkan hak masyarakat bagi peningkatan kehidupan ekonomi, sosial dan politik. Oleh sebab itu, pemberdayaan masyarakat amat penting untuk mengatasi ketidak mampuan masyarakat yang disebabkan oleh keterbatasan akses, kurangnya pengetahuan dan keterampilan, adanya kondisi kemiskinan yang dialami sebagaian masyarakat, dan adanya keengganan untuk membagi wewenang dan sumber daya yang berada pada pemerintah kepada masyarakat. Potensi masyarakat untuk mengembangkan kelembagaan keswadayaan ternyata telah meningkat akibat kemajuan sosial ekonomi masyarakat. Pada masa depan perlu dikembangkan lebih lanjut potensi keswadayaan masyarakat, terutama keterlibatan masyarakat pada berbagai kegiatan yang dapat meningkatkan ketahanan sosial, dan kepedulian mayarakat luas dalam memecahkan masalah kemasyarakatan. Potensi masyarakat tersebut di atas, dalam hal ini Konsep pemberdayaan masyarakat menjadi suatu konsep pembangunan ekonomi baru yang menyangkut banyak nilai-nilai sosial masyarakat, yang bersifat people-centered, participatory, empowering, and sustainable (Chambers, 1995 dalam Kartasasmita, 1996). Konsep ini menurut Friedmann (1992) disebut alternative development, yang menghendaki inclusive democracy, appropriate economic growth, gender equality and intergenerational equity . Hal yang perlu diketahui dari konsep pemberdayaan ini adalah pada dasarnya pemberdayaan tidak mempertentangkan pertumbuhan dengan pemerataan. 


\section{DAFTAR PUSTAKA}

Ndraha, Taliziduhu. 1990. Pembangunan Masyarakat. Rineka Cipta. Jakarta

Friedman, John, Empowerment: The Politics of Alternative Development. Cambridge: Blackwell, 1992.

Chandrakirana, K.S. dan Sadoko, I. (1994). Jakarta Economic Conditions. Center for Policy and Implementation Studies.

Undang Undang No. 9 Tahun 1995 Tentang Usaha Kecil

Brown, Donald. Poverty-Growth Dichotomy . Uner Kirdar dan Leonard Silk (eds.), People: From Impoverishment to Empowerment. New York: New York University Press, 1995.

Chambers, Robert. Poverty and Livelihoods: Whose Reality Counts? Uner Kirdar dan Leonard Silk (eds.), People: From Impoverishment to Empowerment. New York: New York University Press, 1995.

Prijono, O.S dan Pranarka, A.M.W (1996). Pemberdayan: Konsep, Kebijakan dan Implementasi. CSIS; Jakarta h.: 269: 1-4.

Kartasasmita, Ginandjar. 1996. Pembangunan Untuk Rakyat. Memadukan Pertumbuhan dan Pemerataan. Jakarta: PT. Pustaka Cidesindo.

Nawawi, H. Hadari. (1998). Metode Penelitian Bidang Sosial. Yogyakarta: Gajah Mada University Press. 